\title{
The Woman Rabbi (Rabínka)
}

\author{
Author: Anna Grusková
}

First Published: Glosolália (review), (2) 2013

Translations: Czech (Rabinka, 2008); English (The Woman Rabbi, 2008); Italian (La Rabbina, 2011); Polish (Rabinka, 2017).

Theatre Adaptations: Teatro Reon, Bologna (2010); Slovenské národné divadlo, Bratislava (2012).

Public Readings: Teatro di Roma (In altre parole), Rome (2011); Bohemian National Hall, New York (2014); Festival of the New Theatre, Rzeszów (2017); Teatr przy stole (Theatre at the Table), Sopot (2018).

About the Author: Anna Grusková (1962) is a theatre and film director, playwright, screenwriter, theatre scientist and curator. She graduated from the theatre and film science at the Charles University in Prague. Her doctoral studies took place at the Slovak Academy of Sciences in Bratislava. She worked as a lecturer at the Academy of Performing Arts in Bratislava, then in the Bratislava Theatre Institute and as editor-in-chief of the review Medzičasopis. In 2001, she spent three months in India. After return she started focusing on art - theatre and television dramaturgy, acting, directing, writing radio and theatre plays, prose, poetry as well as translating. She has staged productions with mentally challenged actors, homeless people and social workers, she co-operates with professional theatres in Slovakia and abroad. In this way she has directed the play The Bloody Key (with Uršula Kovalyk, 2004), her adaption of Arthur Schnitzler play Five Courses for Two Persons (2009), as well as the collection of short international plays Danube Drama or Ugly Coffee and Cheap Cigarettes (2010). She has written plays for Slovak Radio, such as A Turkish Fancy for Women (1996) about the Austrian painter Gustav Klimt or Almtraum (2004) about Alma Mahler-Werfel; she has adapted the Indian fables Panchatantra (2002) and the Sanskrit epic poem Mahabharata (2004).

Grusková has initiated important Slovak and international social and theatre projects like Brides (2007-2009) or Sarcophaguses and Cashpoints (2008-2009) and she has written the core play for the Czech Project of the Archa Theatre Chance ' 89 (2009), with an intention to create theatre plays reflecting the life in Czechoslovakia and Slovakia before and after the Velvet Revolution. In 2012, she became a film director. She has directed, among others, the docufilm The Woman Rabbi (2012) and A Return to the Burning House (2014) dedicated to Haviva Reick who was one of the parachutists sent by the Jewish Agency on military missions in Slovakia in 1944. She writes both in Slovak and Czech language and translates from the German into Slovak (Arthur Schnitzler, Hans-Thies Lehmann).

Ә Open Access. ( 2021 Agata Firlej, published by De Gruyter. (cc) BY-NC-ND This work is licensed under a Creative Commons Attribution-NonCommercial-NoDerivatives 4.0 License. https://doi.org/10.1515/9783110671056-112 


\section{Content and Interpretation}

The Slovak Republik (1939-1945) was formally independent but in fact it was a puppet state of Nazi Germany. In September of 1941 the so-called "Jewish Codex" was declared in Slovakia. The rights of the Jews were substantially restricted. In the spring 1942, the first wave of Jewish transports by Slovak authorities was organised. Within several months, 58,000 Slovak Jews were transported to Auschwitz and other extermination camps and ghettos. The second wave of Jewish transports followed from September 1944, when German troops invaded Slovakia to suppress the Slovak National Uprising. And another 13,500 Jews were deported and hundreds more were murdered in Slovakia. An estimated 68,000 to 71,000 Slovak Jews were killed, which was more than 80 percent of the prewar Jewish population.

The Woman Rabbi presents the brave efforts of a group of Slovak Jews to prevent these transports. The main character of all versions (see below) of The Woman Rabbi is Gisi (Gisela) Fleischmann, a real Jewish social activist (1892-1944). She was a member of the Slovak Jewish Council (Judenrat), appointed to the initiative of the German authorities in order to facilitate the deportations of the Jews. At the same time, she was one of the founders of the illegal Working Group that sabotaged the activities of the official Council. She tried in every possible way to influence Slovak and German officials to stop or at least to delay or diminish the deportations. It happened mainly through the bribery of high officials including the Nazi "advisor for the Jewish question in Slovakia" Dieter Wisliceny. The money for the effort was obtained from international Jewish organisations. Gisi's illegal activities were finally betrayed, she was arrested and in October of 1944 sent to Auschwitz where she was killed.

Gisi talks with her mother, one of her daughters and two of her friends, and each scene shows the multilayered situation of the character. She is a daughter, mother and an activist and all these roles are impossible to connect. She is also shown as a reflective, highly moral and complicated person with many doubts and with normal human weaknesses.

Gisi: Sometimes I imagine that we are train stations and between us run fast trains and local trains. They carry to us desires, friendship, success and love... but also loss, hatred and anger. We may feel that they are on the way, some still far off, some closer, some just a few tens of meters away, but until they arrive, it's as if they don't exist at all.

We don't know their schedules, and so we stand on the platform, and wait until their lights appear in the distance, and we try to guess which train will stop at our station and when we'll hear the screech of their brakes... (Grusková, 2012, p. 79).

Gisi Fleischmann united the Slovak Jewish community and this is the reason that she is in the play called the Woman Rabbi: she acted as a spiritual leader, protector and an authority, but also as a servant who voluntarily gave up her own family life to serve the community. The content of the play mainly concerns all these difficult choices and decisions that Gisi Fleischmann had to make. The main character is entangled in the necessity to endure her mother's allegations of neglecting the family, and her two 
daughters' incomprehension and sorrow. On the other hand she is shown as a strong personality, who negotiates with German officials in a hard and determined way.

\section{Main Topics and Problems}

Anna Grusková has elaborated three versions of the play as well as a radio trilogy and a documentary film, each under the title The Woman Rabbi (Rabinka), and all of them based on the author's first play from 2006 and subsequently enriched with new additional storylines and facts.

It is necessary to remember that Grusková's narrative has evolved over time: the first version from 2006, firstly concentrated on Gisi Fleischmann's choices, decisions and relations with her family while the following versions (radio play, theatre plays, film) were enriched with some background information regarding the historical and political context of the fate of Slovak Jews during the war.

In all three versions of her play, Grusková experimented with the dramatic form, combining facts and fiction, using some cinematic approaches and the "play within a play” device in order to enrich the story with an allusion to Queen Esther's story from the Hebrew Bible (Old Testament). On the other hand, it is close to so-called docudramas (for instance Peter Weiss, Rolf Hochhuth and Arnošt Goldflam's $\rightarrow$ Sweet Theresienstadt, to some extent Thomas Bernhard or Joshua Sobol). They put for the question of the responsibility not only of perpetrators, but also of the ordinary citizens or even of the victims.

It is also indicated by theatre critics that in addition to the gender dimension of Grusková's story - considered as a way to show the female experience of the war and the Holocaust $\rightarrow$ A Private Conversation, $\rightarrow$ Doctor Josef's Beauty, $\rightarrow$ Hannah, $\rightarrow$ The Land of Forgetting, $\rightarrow$ The Sound of the Sundial. It also contains yet another aspect: the cultural memory of the space. The playwright restores the historical narrative of Bratislava, and of a forgotten episode and person, which deserves to be remembered.

The activities of Gisi Fleischmann as well as Grusková's play inspired the Israeli film director Natascha Dudinski to create her documentary film Gisi (2014).

\section{Cited Work}

Grusková, A. (2012). Rabínka. Bulletin, Slovenské národné divadlo. (Bulletin of the performance, Slovak National Theatre.) Bratislava: Slovenské národné divadlo.

\section{Further References}

Campion, J. (1987). In the Lion's Mouth: Gisi Fleischmann \& the Jewish Fight for Survival. Lanham: University Press of America. Grusková, A. (2009). Nemlčat. Žena v literatúre (Interview). Knižná revue, 19(4), p. 11. Hradská, K. (ed.) (2003). Holokaust na Slovensku 3. Listy Gisely Fleischmannovej (1942-1944). Bratislava: Nadácia Milana Šimečku. Hradská, K. (2012). Gizi Fleischmannová. Návrat nežiadúci. Bratislava: Marenčin. Kročanová, D. (2017). The Holocaust in Slovak Drama. Poznańskie Studia Slawistyczne, 6(12), pp. 197-210. Neštáková, D. (2017). Gisi Fleischmann - przywódczyni 
Żydów na Słowacji podczas II wojnyświatowej. In: M. Grądzka-Rejak, A. Namysło, eds., Elity i przedstawiciele społeczności żydowskiej podczas II wojny światowej. Warszawa: Instytut Pamięci Narodowej, pp. 473-489. Neumann, Y. O. (1970). Gisi Fleischmann. Die Geschichte einer Kämpferin. Tel Aviv: WIZO.

$\mathrm{AF}$ 